Supporting Information (SI)

\title{
Multifunctional linear triferrocene derivatives linked by oxidizable bridges: optical, electronic and cation sensing properties.
}

\author{
Antonio Caballero, Alberto Tárraga, * María D. Velasco, Arturo Espinosa and Pedro \\ Molina* \\ Departamento de Química Orgánica. Factultad de Química. Universidad de Murcia. \\ Campus de Espinardo, E-30100 Murcia, Spain.
}

E-mail:pmolina@um.es

\section{$\underline{\text { Table of contents }}$}

General comments

Relevant spectral and characterization data of triferrocene derivatives $\mathbf{1}$ and $\mathbf{2}$ S4

Figure 1. CV of compound 1

Figure 2. CV of compound $2+$ S6

$\begin{array}{ll}\text { Figure 3. UV-vis spectra of compound } \mathbf{1} & \text { S7 }\end{array}$

$\begin{array}{ll}\text { Figure 4. UV-vis spectra of compound 2. S8 } & \text { S8 }\end{array}$

General procedures for the generation of the oxidized species $\quad$ S9

Figure 5. Evolution of the Vis-near IR spectra during the oxidation of $2 \quad$ S10 
Figure 6. Deconvolution of NIR spectra of the oxidized species

LMCT and IVCT band parameters, obtained from the spectral

deconvolution, and calculated intramolecular electron transfer (IET)

parameters for the oxidized species.

Figure 7. Evolution of the $\mathrm{CV}$ of $\mathbf{1}$ upon addition of $\mathrm{Mg}^{2+}$

Figure 8. Evolution of the CV and DPV of 2 upon addition of $\mathrm{Mg}^{2+}$

Figure 9. Titration isotherm of $\mathbf{1}$

Figure10. Evolution of the UV-vis of 2 upon addition of $\mathrm{Mg}^{2+}$

Figure 11. Perspective view for the B3LYP/3-21G* optimized structures of compounds $\mathbf{1}$ and $\mathbf{2}$

Figure 12. Optimized structure (B3LYP/3-21G*) for the complex formed upon addition of $\mathrm{Mg}\left(\mathrm{ClO}_{4}\right)_{2}$ to 1 .

Figure 13. Evolution of the ${ }^{1} \mathrm{H}-\mathrm{NMR}$ spectrum of $\mathbf{1}$ upon addition of $\mathrm{Mg}^{2+} \quad \mathrm{S} 20$

Figure 14. Evolution of the ${ }^{1} \mathrm{H}-\mathrm{NMR}$ spectrum of $\mathbf{2}$ upon addition of $\mathrm{Mg}^{2+} \quad \mathrm{S} 21$

References

S22 


\section{General comments.-}

Melting points were determined on a Kofler hot-plate melting point apparatus and are uncorrected. IR spectra were determined as Nujol emulsions or films on a Nicolet Impact 400 spectrophotometer. ${ }^{1} \mathrm{H}$ - and ${ }^{13} \mathrm{C}-\mathrm{NMR}$ spectra were recorded on a Varian Unity $300(300 \mathrm{MHz})$. Chemical shifts refer to signals of tetramethylsilane in the case of ${ }^{1} \mathrm{H}$ and ${ }^{13} \mathrm{C}$ spectra. The EI mass spectra were recorded on a Fisons AUTOSPEC 500 VG spectrometer. Microanalyses were performed on a Carlo Erba 1108 instrument.

Calculated geometries for the neutral structures $\mathbf{1}$ and $\mathbf{2}$, as well as for the complexation studies between 1 and $\mathrm{Mg}^{2+}$ cation, were fully optimized with the Gaussian $03^{1}$ package at the DFT ${ }^{2}$ B3LYP/3-21G* level of theory, after imposing the final resulting $\mathrm{C}_{\mathrm{i}}(\mathbf{1})$ or $\mathrm{C}_{2}\left(\mathbf{2}\right.$ and $\mathbf{1} \cdot \mathrm{Mg}^{2+}$ complex $)$ symmetries.

Electrochemical measurements were carried out on a Bioanalytical Systems CV-50W Voltammetric Analyzer. Electrochemical experiments were conducted in a conventional three-electrode cell under a nitrogen atmosphere at $25{ }^{\circ} \mathrm{C}$. The working electrode was a Pt disk (1.6 mm in diameter), polished before each recording, for voltammperometric measurements and a mesh for spectroelectrochemical experiments. The auxiliary electrode was a platinum wire. The reference electrode was SCE, and decamethylferrocene (DMFC, $-0.07 \mathrm{~V}$ vs SCE) was used as an internal reference both for potential calibration and for reversibility criteria. The experiments were carried out in dichloromethane solutions containing $0.1 \mathrm{M}\left[(n-\mathrm{Bu})_{4} \mathrm{~N}\right] \mathrm{ClO}_{4}$ or $0.1 \mathrm{M}\left[(n-\mathrm{Bu})_{4} \mathrm{~N}\right] \mathrm{PF}_{6}$ as supporting electrolyte. Deoxygenation of the solutions was achieved by bubbling nitrogen for at least $10 \mathrm{~min}$ and the working electrode was cleaned after each run and the cyclic voltammograms were recorded with a scan rate increasing from 0.05 to 1.00 $\mathrm{Vs}^{-1}$. 


\section{Relevant spectral and characterization data of triferrocene derivatives 1 and 2.-}

1,1'-Bis(2-aza-4-ferrocenyl-1,3-butadien-4-yl)ferrocene 1: Yield: 92\%; mp>350 ${ }^{\circ} \mathrm{C}$. IR (Nujol) $v_{\max } 1633,1576,1434,1372,1247,1184,1116,1031,883,752,695 .{ }^{1} \mathrm{H}$ NMR $\left(\mathrm{CDCl}_{3}\right): \delta=8.07(\mathrm{~s}, 2 \mathrm{H}), 6.99(\mathrm{~d}, 2 \mathrm{H}, J=14.0 \mathrm{~Hz}), 6.58(\mathrm{~d}, 2 \mathrm{H}, J=14.0 \mathrm{~Hz}), 4.69(\mathrm{t}, 4 \mathrm{H}$, $J=1.8 \mathrm{~Hz}), 4.44(\mathrm{t}, 4 \mathrm{H}, J=1.8 \mathrm{~Hz}), 4.40(\mathrm{t}, 4 \mathrm{H}, J=1.8 \mathrm{~Hz}), 4.33(\mathrm{t}, 4 \mathrm{H}, J=1.8 \mathrm{~Hz}), 4.20$ (s, 10H). ${ }^{13} \mathrm{C} \mathrm{NMR}\left(\mathrm{CDCl}_{3}\right): \delta=158.90,140.81,125.72,82.90,80.91,71.00,70.30$, 69.71, 69.32, 68.93, 68.22. MS (EI): m/z (\%): $660\left(\mathrm{M}^{+}, 100\right), 423$ (50), 358 (98), 330 (34), 121 (46). Anal Calc for $\mathrm{C}_{36} \mathrm{H}_{32} \mathrm{Fe}_{3} \mathrm{~N}_{2}$ : C, 65.49; H, 4.89; N, 4.24. Found: C, 65.33; H, 5.04; N, 3.99 .

1,1'-Bis(2-aza-4-ferrocenyl-1,3-butadien-1-yl)ferrocene 2: Yield: 90\%; mp>350 C. IR (Nujol) $v_{\max } 1640,1580,1434,1368,1229,1182,1116,1030,877,758,698 .{ }^{1} \mathrm{H}$ NMR $\left(\mathrm{CDCl}_{3}\right): \delta=7.97(\mathrm{~s}, 2 \mathrm{H}), 7.00(\mathrm{~d}, 2 \mathrm{H}, J=12.0 \mathrm{~Hz}), 6.65(\mathrm{~d}, 2 \mathrm{H}, J=12.0 \mathrm{~Hz}), 4.79(\mathrm{t}, 4 \mathrm{H}$, $J=1.8 \mathrm{~Hz}), 4.45(\mathrm{t}, 4 \mathrm{H}, J=1.8 \mathrm{~Hz}), 4.37(\mathrm{t}, 4 \mathrm{H}, J=1.8 \mathrm{~Hz}), 4.27(\mathrm{t}, 4 \mathrm{H}, J=1.8 \mathrm{~Hz}), 4.14$ (s, 10H). ${ }^{13} \mathrm{C} \mathrm{NMR}\left(\mathrm{CDCl}_{3}\right): \delta=159.15,140.25,127.39,82.21,81.92,73.28,72.06$, 69.73, 69.37, 69,18, 67,11. MS (EI): m/z (\%): $660\left(\mathrm{M}^{+}, 100\right), 595$ (30), $476(30), 358$ (70), 330 (43), 130 (46). Anal Calc for $\mathrm{C}_{36} \mathrm{H}_{32} \mathrm{Fe}_{3} \mathrm{~N}_{2}$ : C, 65.49; H, 4.89; N, 4.24. Found: C, 65.28; H, 5.16; N, 4.21. 

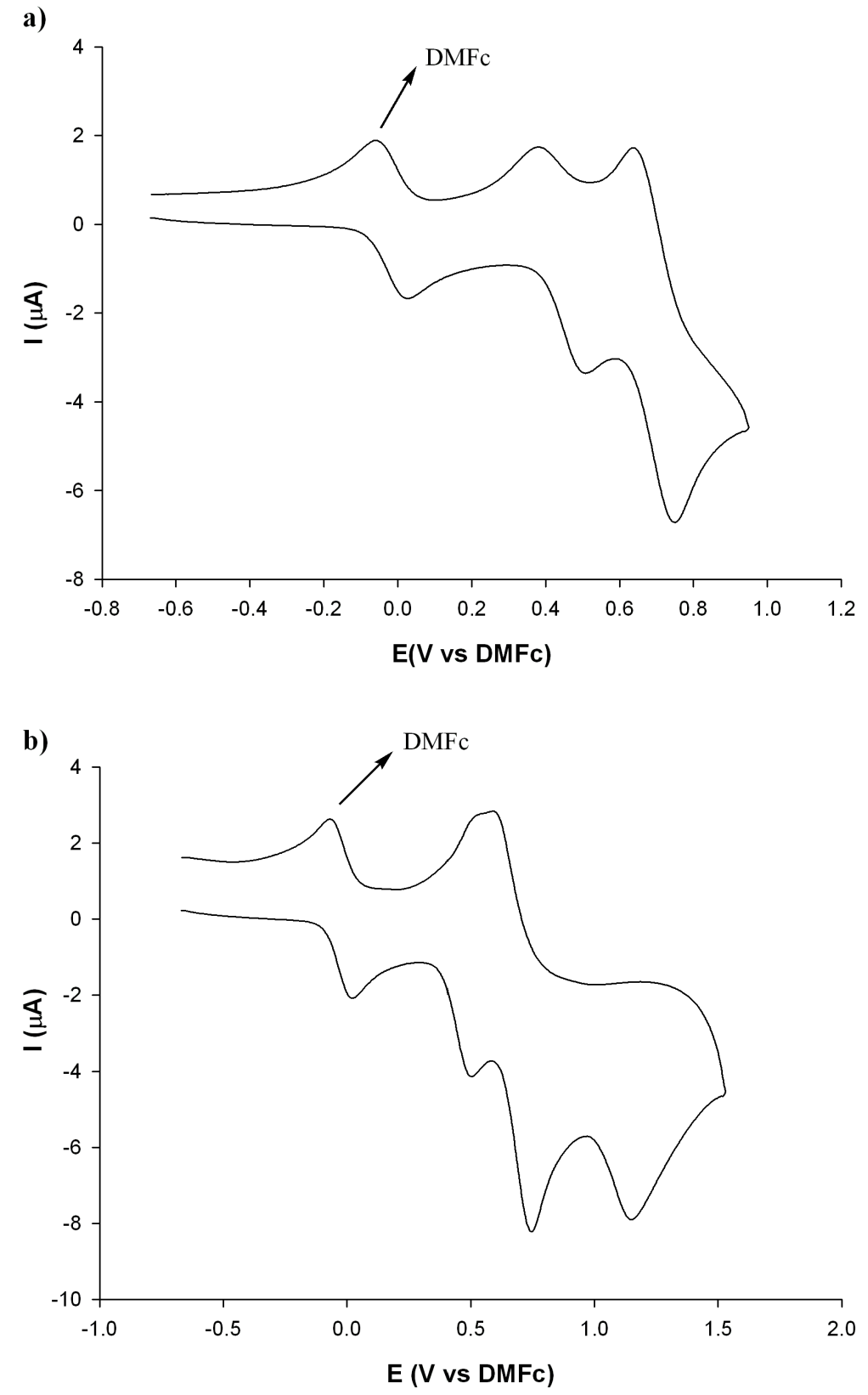

Figure 1. $\mathrm{CV}$ of compound $\mathrm{1}(1 \mathrm{mM})$ in $\mathrm{CH}_{2} \mathrm{Cl}_{2} /\left[(n-\mathrm{Bu})_{4} \mathrm{~N}\right] \mathrm{ClO}_{4}$ scanned at $0.2 \mathrm{Vs}^{-1}$ (a) from -0.7 to $0.95 \mathrm{~V}$; (b) from -0.7 to $1.5 \mathrm{~V}$. 

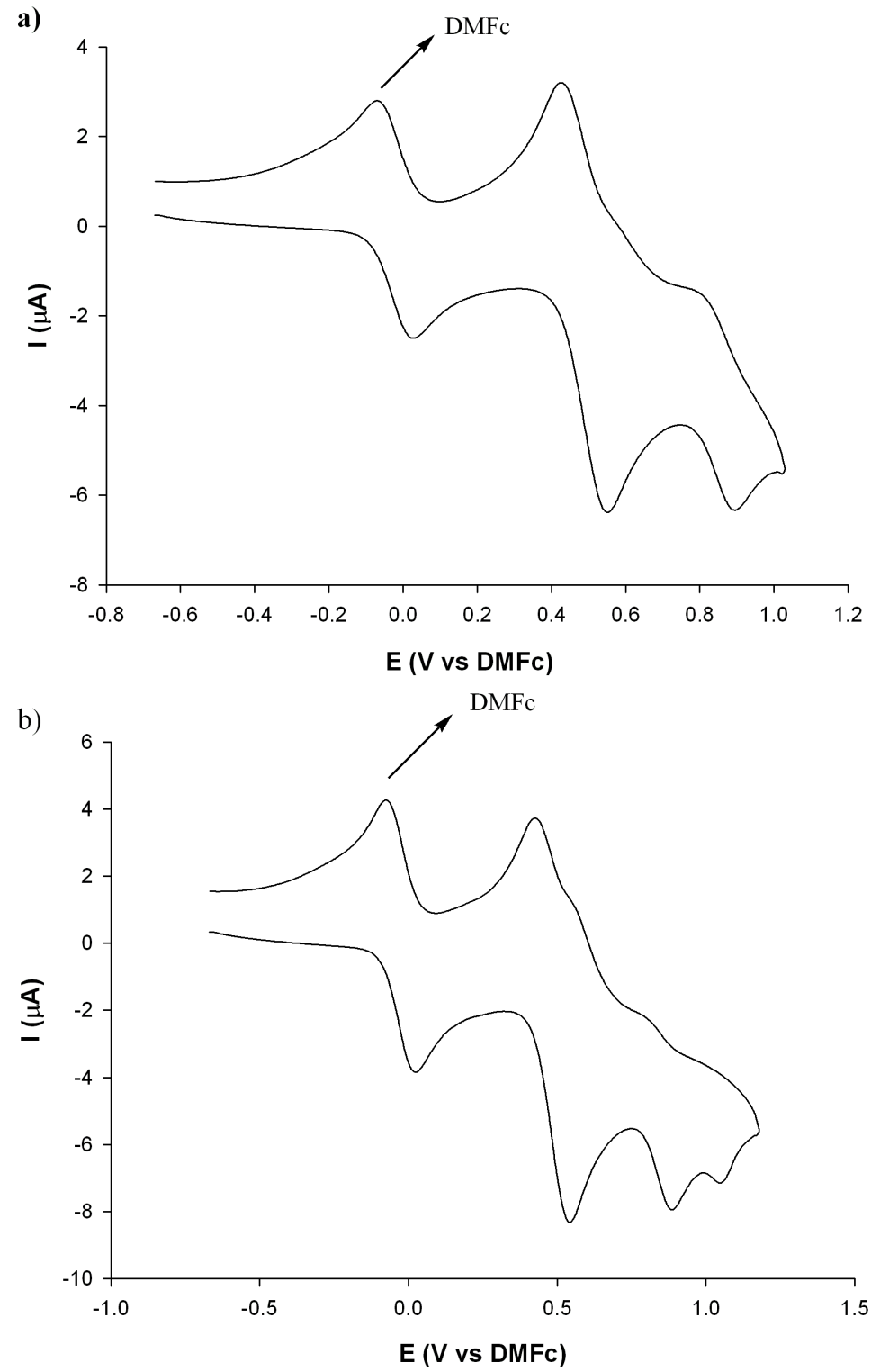

Figure 2. $\mathrm{CV}$ of compound $2(1 \mathrm{mM})$ in $\mathrm{CH}_{2} \mathrm{Cl}_{2} /\left[(n-\mathrm{Bu})_{4} \mathrm{~N}\right] \mathrm{ClO}_{4}$ scanned at $0.2 \mathrm{Vs}^{-1}$ (a) from -0.7 to $1.1 \mathrm{~V}$; (b) from -0.7 to $1.25 \mathrm{~V}$. 


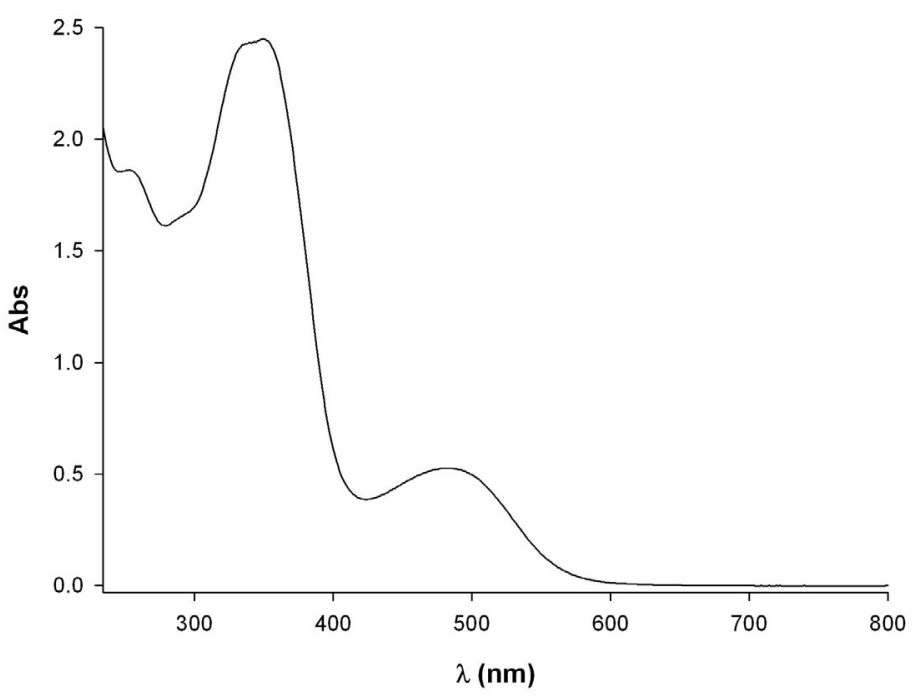

Figure 3. UV-vis spectra of compound 1 in $\mathrm{CH}_{2} \mathrm{Cl}_{2}\left(\mathrm{c}=1 \times 10^{-4} \mathrm{M}\right)$. 


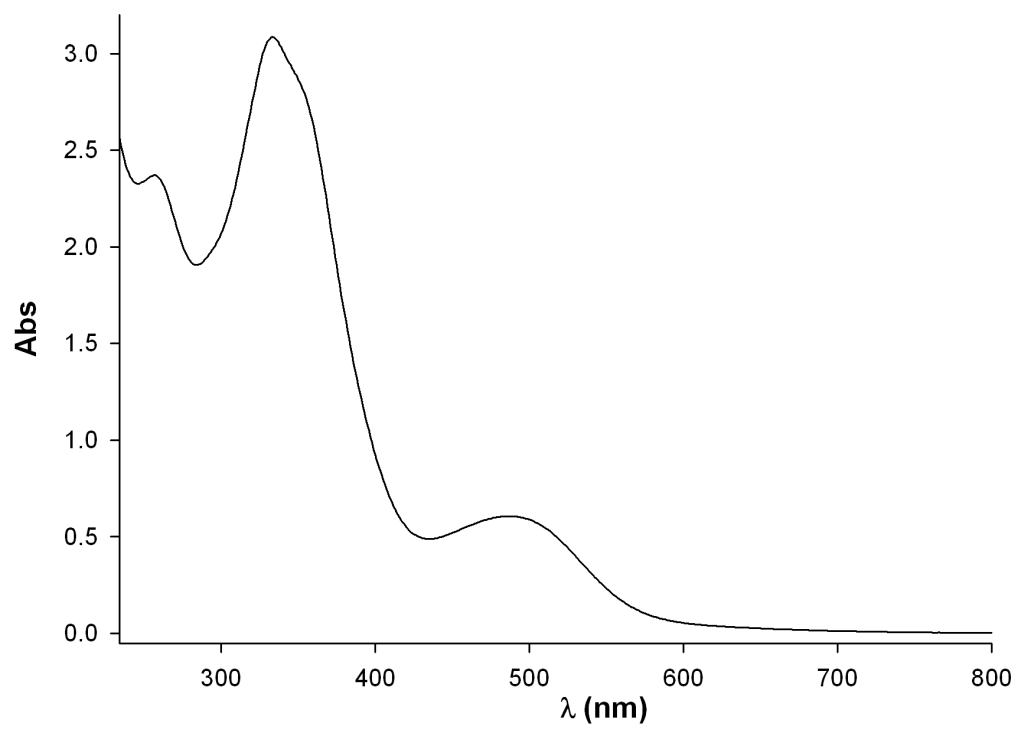

Figure 4. UV-vis spectra of compound 2 in $\mathrm{CH}_{2} \mathrm{Cl}_{2}\left(\mathrm{c}=1 \times 10^{-4} \mathrm{M}\right)$. 
General procedure for the electrochemical oxidation of 1 and 2.- The generation of the oxidized species derived from 1 and 2 was carried out on $\mathrm{CH}_{2} \mathrm{Cl}_{2}$ solutions $(\mathrm{c}=$ $\left.1 \times 10^{-3} \mathrm{M}\right)$, using $\left.\left[(n-\mathrm{Bu})_{4} \mathrm{~N}\right)\right] \mathrm{PF}_{6}(0.15 \mathrm{M})$ as supporting electrolyte and a constant potential electrolysis of $0.12 \mathrm{~V}$ above the $\mathrm{E}_{1 / 2}$ of the ferrocenyl redox couple: at $0.59 \mathrm{~V}$ and $0.81 \mathrm{~V}$ for compound 1 and $0.63 \mathrm{~V}$ and $0.96 \mathrm{~V}$ for compound 2 . The number of electrons removed was followed by coulometric measurements.

General procedure for the chemical oxidation of 1 and 2.- To a solution of the adequate neutral species $(0.2 \mathrm{~g}, 0.3 \mathrm{mmol})$ in dry toluene $(10 \mathrm{ml})$, a solution of the appropriate amount of $\mathrm{AgCF}_{3} \mathrm{SO}_{3}(0.3,0.6$ or $0.9 \mathrm{mmol})$, in the same solvent $(5 \mathrm{ml})$ and under nitrogen atmosphere, was added. The solution was stirred for $15 \mathrm{~min}$ and then the resulting suspension was filtered off. The solvent was removed under reduced pressure giving rise to the mono-, di- or trioxidized derivative, respectively, in almost quantitative yields. 


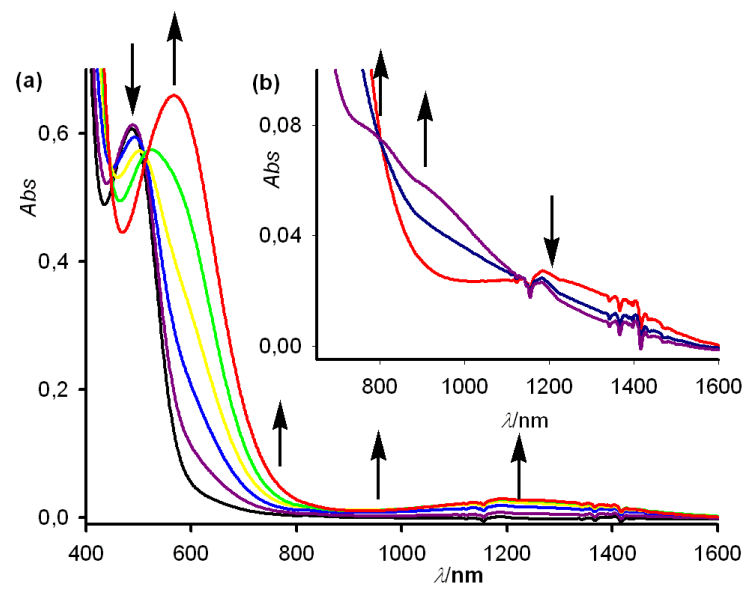

Figure 5. Evolution of the Vis-near IR spectra during the oxidation of $2\left(\mathrm{c}=1 \times 10^{-3} \mathrm{M}\right.$ in $\mathrm{CH}_{2} \mathrm{Cl}_{2}$, with $\left[(n-\mathrm{Bu})_{4} \mathrm{~N}\right] \mathrm{PF}_{6}(0.15 \mathrm{M})$ as supporting electrolyte when: (a) 0 (black), 0.4 (purple), 0.8 (blue), 1.2 (yellow), 1.6 (green) and 2 (red) electrons are removed, and (b) 2 (red), 2.5 (deep blue) and 3 (purple) electrons are removed. 
Figure 6. Deconvolution of NIR spectra of (a) $\mathbf{1}^{+}$, (b) $\mathbf{1}^{+3}$, (c) $\mathbf{2}^{+2}$, (d) $\mathbf{2}^{+3}$. Experimental spectra were deconvoluted by means of Gaussian functions. The sum of the Gaussian functions of (e) $\mathbf{1}^{+}$, (f) $\mathbf{1}^{+3}$, (g) $\mathbf{2}^{\mathbf{+ 2}}$ and (h) $\mathbf{2}^{\mathbf{+ 3}}$ (red line) closely matches the measured spectra (black line).
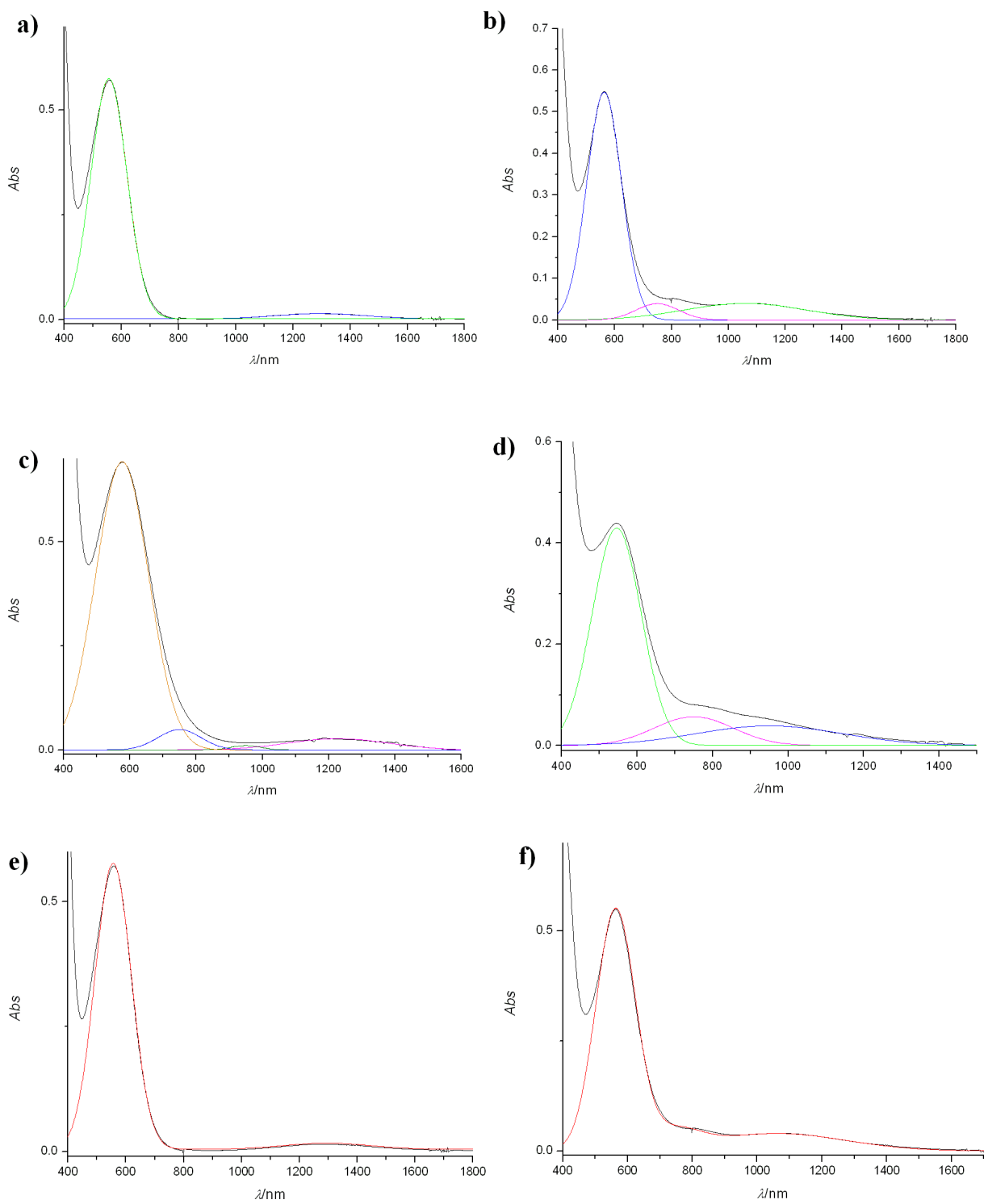


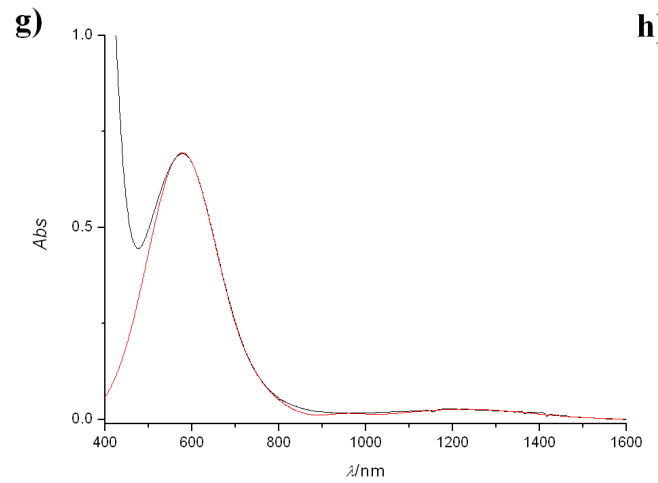

h)

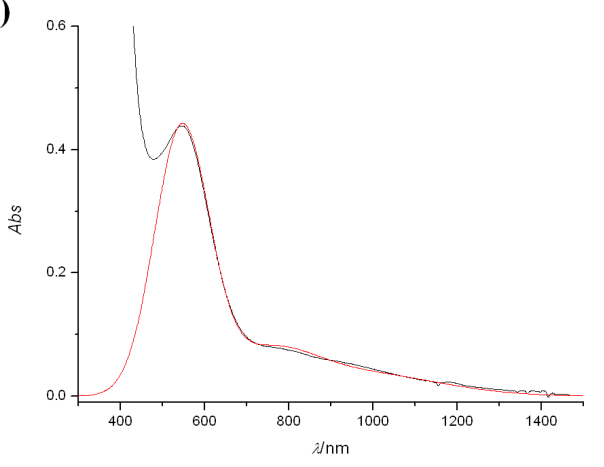


Table 1. LMCT and IVCT band parameters, obtained from the spectral deconvolution, and calculated intramolecular electron transfer (IET) parameters for the oxidized species.

\begin{tabular}{cccccc} 
Compound & $v_{\max }\left(\mathrm{cm}^{-1}\right)$ & $\varepsilon_{\max }\left(\mathrm{M}^{-1} \mathrm{~cm}^{-1}\right)$ & $\Delta v_{1 / 2}\left(\mathrm{~cm}^{-1}\right)$ & $\mathrm{d}(\AA)^{\mathrm{a}}$ & $\mathrm{V}_{\mathrm{ab}}\left(\mathrm{cm}^{-1}\right)$ \\
\hline $\mathbf{1}^{\mathbf{+}}$ & 7716 & 140 & 1811 & 9.175 & $99^{\mathrm{b}}$ \\
$\mathbf{1}^{\mathbf{3}}$ & 13333 & 440 & 2693 & 5.384 & $481^{\mathrm{c}}$ \\
& 9443 & 460 & 3779 & 5.384 & $504^{\mathrm{c}}$ \\
$\mathbf{2}^{2+}$ & 13333 & 500 & 2330 & 5.349 & $478^{\mathrm{c}}$ \\
& 10526 & 110 & 999 & 5.349 & $131^{\mathrm{c}}$ \\
& 8143 & 270 & 2048 & 9.198 & $150^{\mathrm{b}}$ \\
$\mathbf{2}^{3+}$ & 13333 & 590 & 3808 & 5.349 & $663^{\mathrm{c}}$ \\
& 10526 & 390 & 4511 & 5.349 & $522^{\mathrm{c}}$ \\
\hline
\end{tabular}

${ }^{a}$ Effective electron-transfer distances between the $\mathrm{N}$ and $\mathrm{Fe}$ and between the two metallic centers, determined by geometrical optimizations at the DFT level of theory (B3LYP/3-21G*); ${ }^{\mathrm{b}}$ IVCT; ${ }^{\mathrm{c}} \mathrm{LMCT}$. 


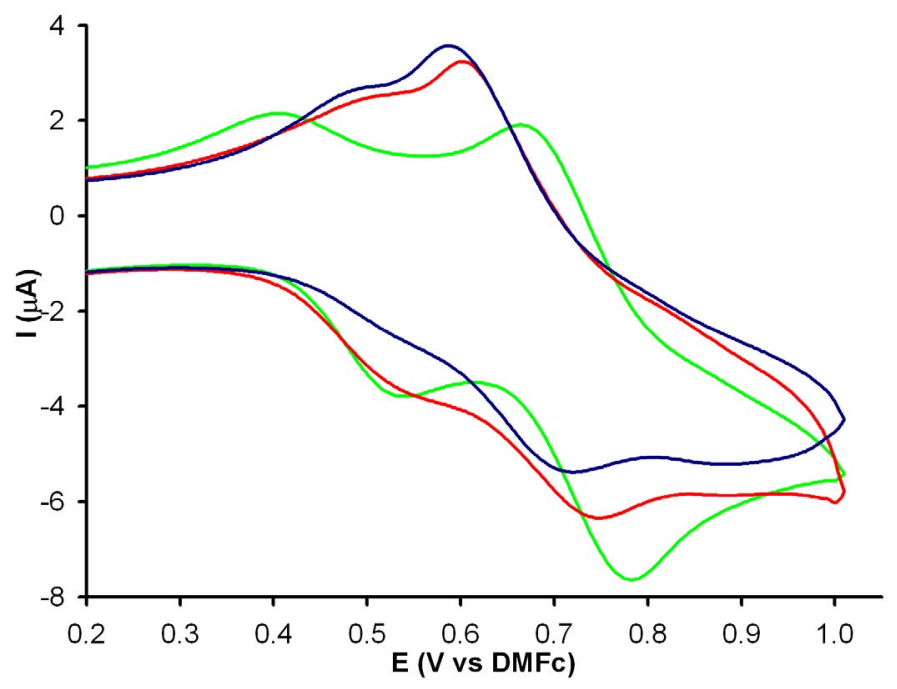

Figure 7.- Evolution of the $\mathrm{CV}$ of $\mathbf{1}(1 \mathrm{mM})$ in $\mathrm{CH}_{2} \mathrm{Cl}_{2} /\left[(n-\mathrm{Bu})_{4} \mathrm{~N}\right] \mathrm{ClO}_{4}$ scanned at 0.1 $\mathrm{Vs}^{-1}$ when: 0 (green), 0.6 (red) and 1 (blue) equiv of $\mathrm{Mg}^{2+}$ is added. 

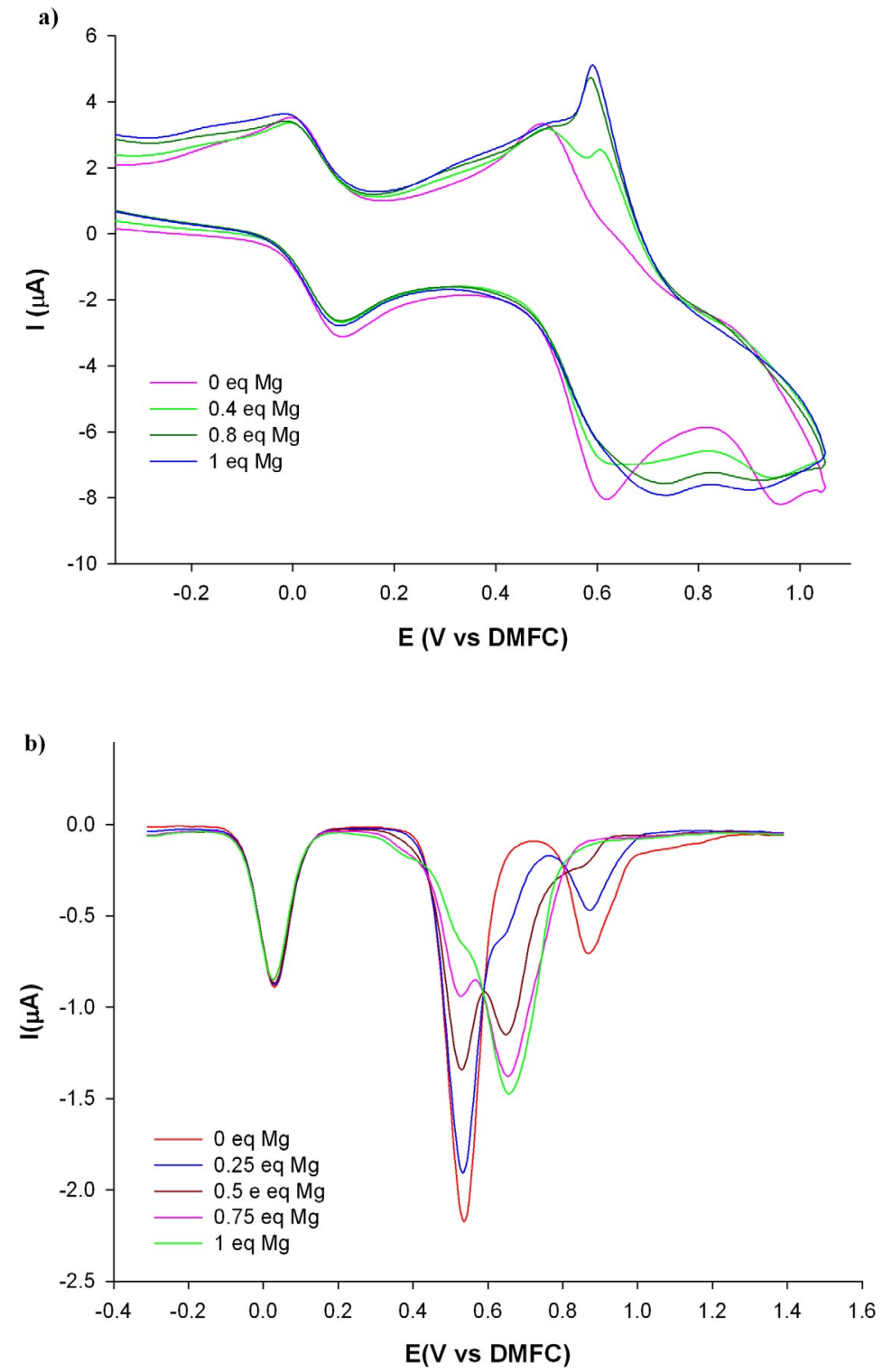

Figure 8. (a) Evolution of the $\mathrm{CV}$ of $2(1 \mathrm{mM})$ in $\left.\mathrm{CH}_{2} \mathrm{Cl}_{2} /[n-\mathrm{Bu})_{4} \mathrm{~N}\right] \mathrm{ClO}_{4}$ scanned at 0.1 $\mathrm{Vs}^{-1}$ from -0.3 to $1.1 \mathrm{~V}$ when several amounts of $\mathrm{Mg}^{2+}$ were added. (b) Evolution of the $\mathrm{CV}$ of $2(1 \mathrm{mM})$ in $\mathrm{CH}_{2} \mathrm{Cl}_{2} /[n-\mathrm{Bu})_{4} \mathrm{NClO}_{4}$ scanned at $0.1 \mathrm{Vs}^{-1}$ from -0.3 to $1.4 \mathrm{~V}$ when several amounts of $\mathrm{Mg}^{2+}$ were added. 


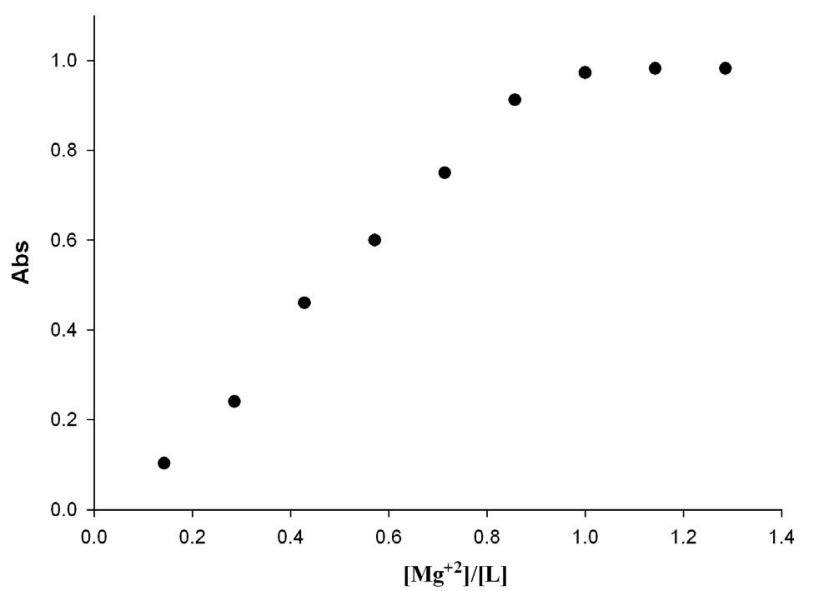

Figure 9. Changes of absorbance at $564 \mathrm{~nm}$, upon addition of $\mathrm{Mg}\left(\mathrm{ClO}_{4}\right)_{2}$ to a $\mathrm{CH}_{2} \mathrm{Cl}_{2}$ solution of 1 . 


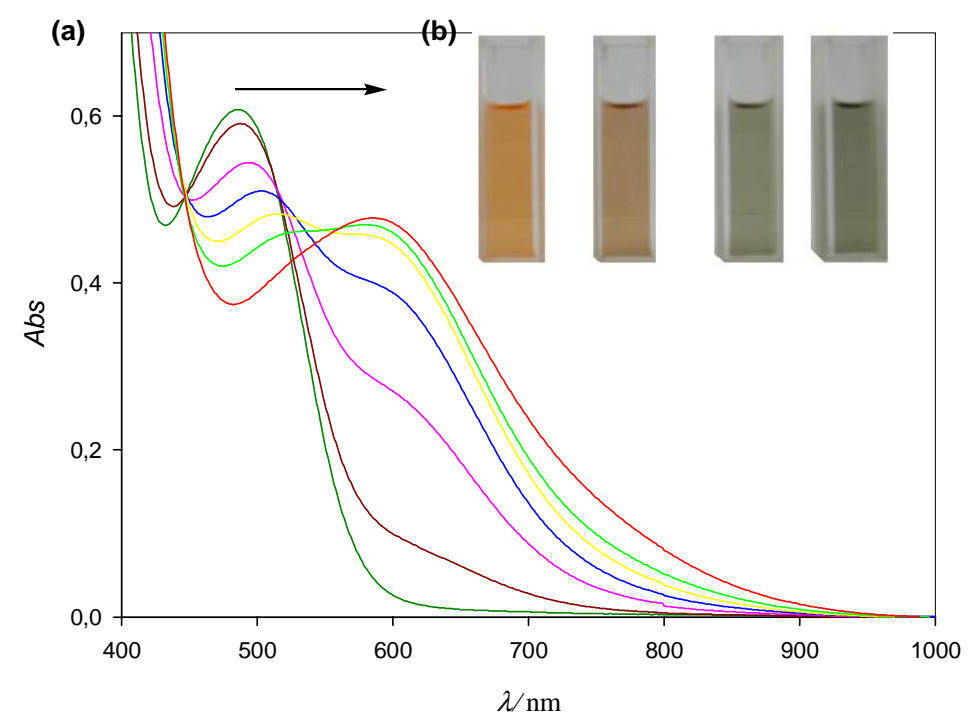

Figure 10.- (a) UV-vis spectra obtained during the titration of 2 with $\mathrm{Mg}\left(\mathrm{ClO}_{4}\right)_{2}$ in $\mathrm{CH}_{2} \mathrm{Cl}_{2}\left(\mathrm{c}=1 \times 10^{-4} \mathrm{M}\right)$ ). The initial spectrum (green) is that of the starting 2 and the final spectrum (red) corresponds to the addition of 1 equiv of $\mathrm{Mg}^{2+}$. (b) Changes of colour observed upon addition of $\mathrm{Mg}^{2+}$ : free ligand (left) and after addition of 1 equiv of $\mathrm{Mg}^{2+}$ (right). 

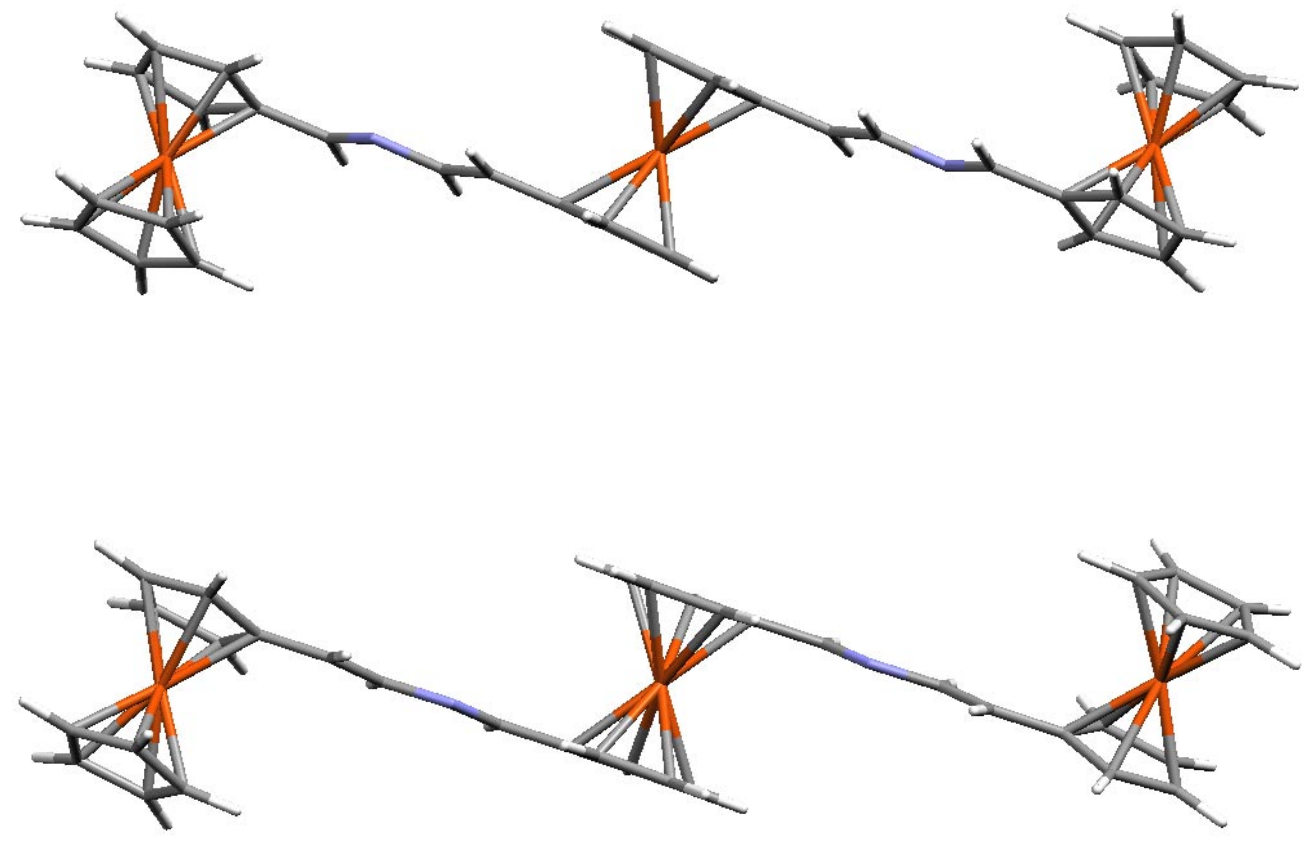

Figure 11.- Perspective view for the B3LYP/3-21G* optimized structures of compounds 1 (top) and $\mathbf{2}$ (bottom). 


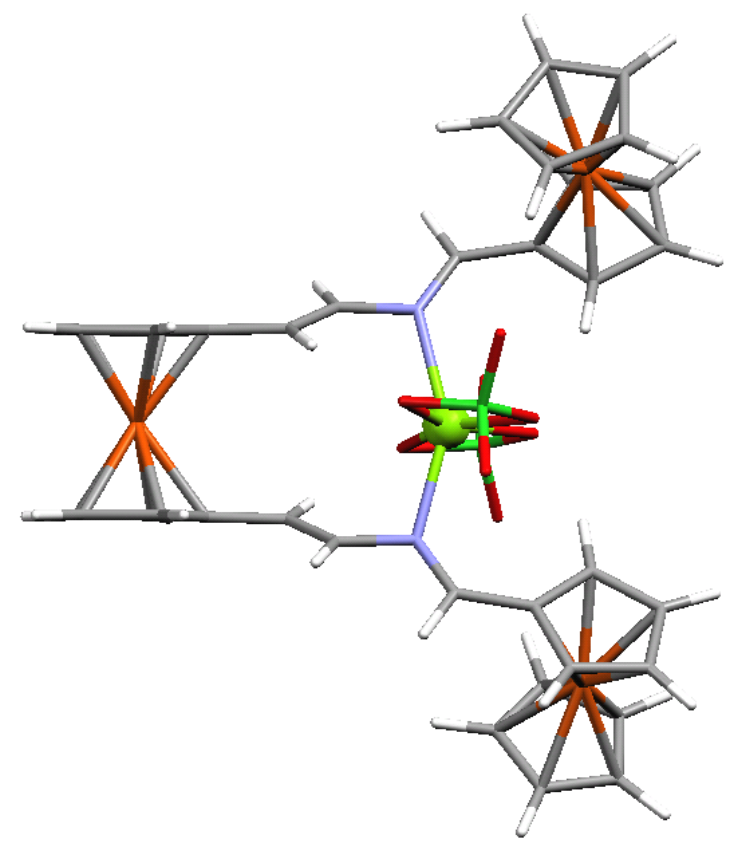

Figure 12. Optimized structure for the complex formed upon addition of $\mathrm{Mg}\left(\mathrm{ClO}_{4}\right)_{2}$ to 1, calculated at the B3LYP/3-21G* level of theory. 

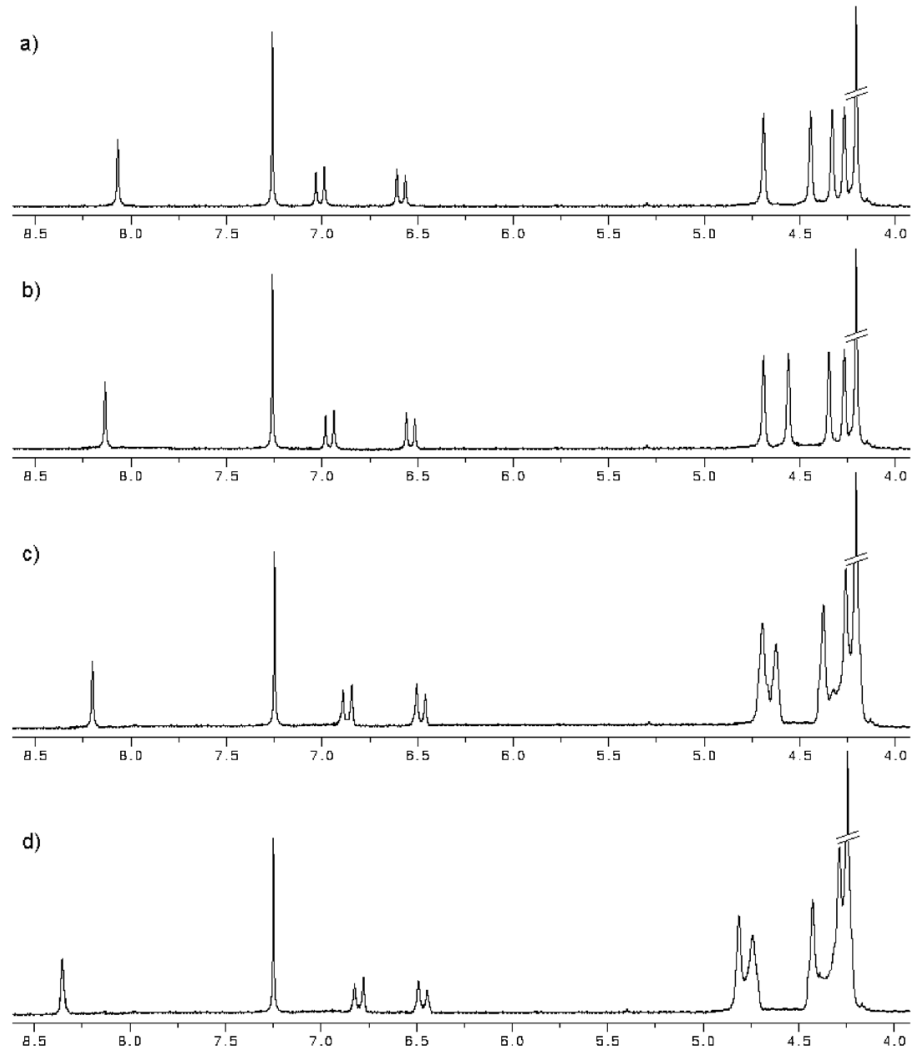

Figure 13. ${ }^{1} \mathrm{H}-\mathrm{NMR}$ spectrum of (a) free ligand $\mathbf{1}\left(\mathrm{c}=1 \times 10^{-3} \mathrm{M}\right)$ and upon addition of (b) 0.33 , (c) 0.66 and (d) 1 equivalent of $\mathrm{Mg}^{2+}$. 


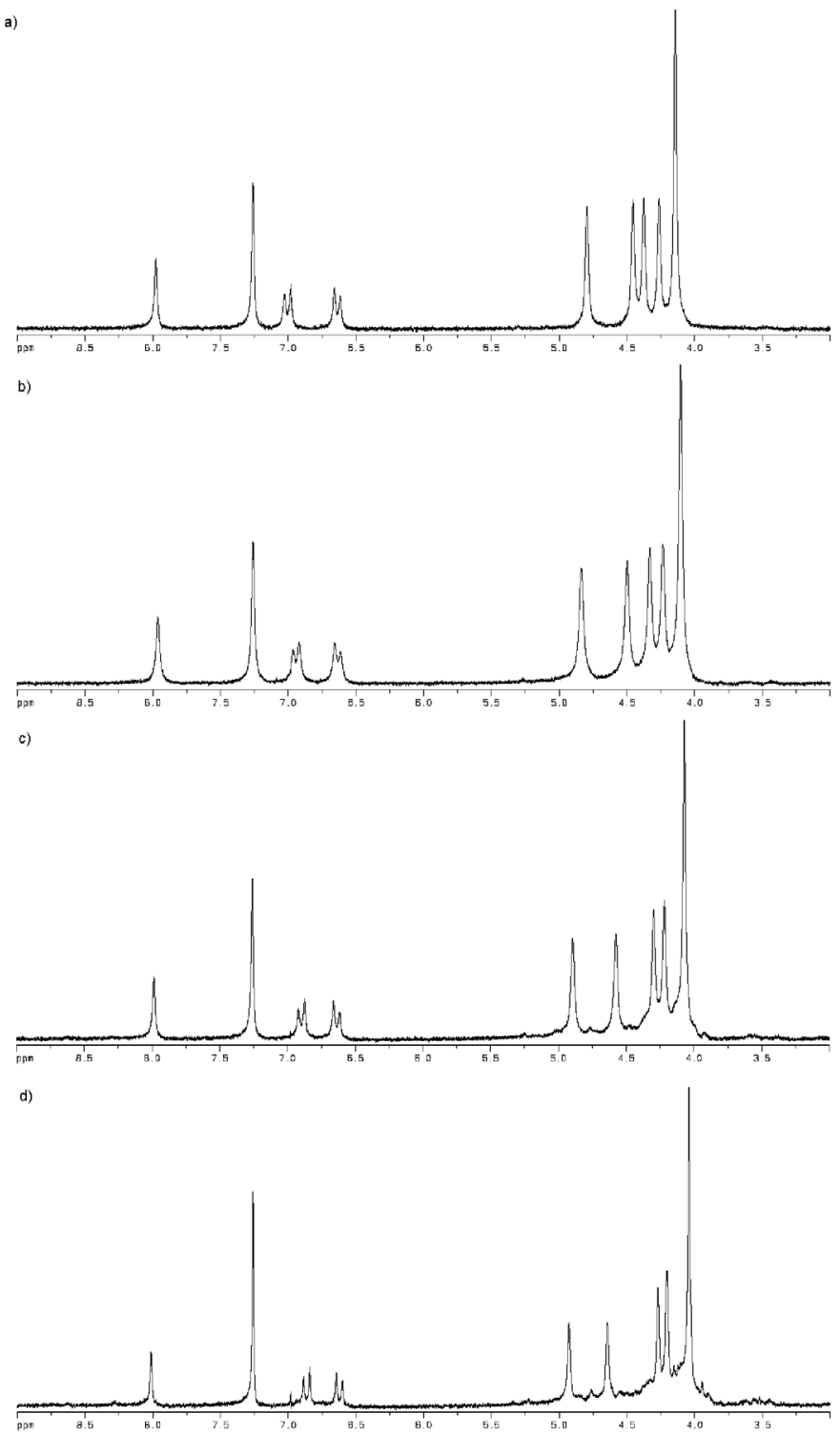

Figure 14. ${ }^{1} \mathrm{H}-\mathrm{NMR}$ spectrum of (a) free ligand $2\left(\mathrm{c}=1 \times 10^{-3} \mathrm{M}\right)$, and upon addition of (b) 0.33 , (c) 0.66 and (d) 1 equivalent of $\mathrm{Mg}^{2+}$. 


\section{References:}

1.- Gaussian 03, Frisch, M.J.; Trucks, G.W.; Schlegel, H.B.; Scuseria, G.E.; Robb, M.A.; Cheeseman, J.R.; Montgomery Jr., J.A.; Vreven, T.; Kudin, K.N.; Burant, J.C.; Millam, J.M.; Iyengar, S.S.; Tomasi, J.; Barone, V.; Mennucci, B.; Cossi, M.; Scalmani, G.; Rega,N.; Peterson, G.A.; Nakatsuji, H.; Hada, M.; Ehara, M.; Toyota, K.; Fukuda, R.; Hasegawa, J.; Ishida, M.; Nakajima, T.; Honda, Y.; Kitao, O.; Nakai, H.; Klene, M.; Li, X.; Knox, J. E.; Hratchian, H. P.; Cross, J. B.; Adamo, C.; Jaramillo, J.;

Gomperts, R.; Stratmann, R. E.; Yazyev, O.; Austin, A. J.; Cammi, R.; Pomelli, C.; Ochterski, J. W.; Ayala, P. Y.; Morokuma, K.; Voth, G. A.; Salvador, P.; Dannenberg, J. J.; Zakrzewski, V. G.; Dapprich, S.; Daniels, A. D.; Strain, M. C.; Farkas, O.; Malick, D. K.; Rabuck,, A. D.; Raghavachari, K.; Foresman J. B.; Ortiz, J. V.; Cui, Q.; Baboul, A. G.; Clifford, S.; Cioslowski, J.; Stefanov, B. B.; Liu, G.; Liashenko, A.; Piskorz, P.; Komaromi, I.; Martin, R. L.; Fox, D. J.; Keith, T.; Al-Laham, M. A.; Peng, C. Y.; Nanayakkara, A.; Challacombe, M.; Gill, P. M. W.; Johnson, B.; Chen, W.; Wong, M. W.; Gonzalez, C.; Pople, J. A. Gaussian, Inc., Pittsburgh PA, 2003.

2.- (a) Baerends, E.J.; Ellis, D.E.; Ros, P. Chem. Phys., 1973, 2, 41. (b) Kohn, W.; Becke, A.D.; Parr, R.G. J. Phys. Chem., 1996, 100, 12974. 